\title{
The Experiences Entailed by the Intersectionality of Korean (Im)migrant Mothers' Multi- identities in Layered Contact Zones of the United States
}

SU JIN PARK

BETH LEWIS SAMUELSON

Indiana University Bloomington

\begin{abstract}
Pratt's (1991) notion of "contact zone" was used to investigate the lives of four Korean (im)migrant mothers in the United States, where they encountered clashes of languages and cultures. This study, part of five-year feminist cyber-ethnography, is an examination of their contact zone experiences from the perspective of the intersectionality (Crenshaw, 1989) of their multiple identities, which were complicated and added layers to the contact zones usually presumed to be experienced by (im)migrant adults when regarded a single category despite great diversity of their pre-migration capital (Bourdieu, 1991). The participants' identity as mothers exacerbated confrontations in some contact zones, and their intertwined identities as highly-educated and motivated Korean women and wives situated them in both outside- within-ethnic contact zones.
\end{abstract}

Keywords: Contact zone(s), Korean (im)migrant mothers, intersectionality, feminist cyber-ethnography

\section{Introduction}

Globalization has brought increasing numbers of Korean (im)migrants to the United States, either temporarily or permanently. According to the U.S. Census Bureau (2010), there were over 1.4 million Korean immigrants in the United States as of 2010. Ogbu and Simons (1998) classified Korean (im)migrants as "voluntary minorities," as few were forced to migrate. That their migration was voluntary might be assumed to mitigate the severity of difficulties 
Korean (im)migrants experience as they pursue the beacon of hope that is the so-called American dream, yet neither absence of compulsion nor inspiration can completely spare them the hardships of migration. No matter whether it is voluntary or involuntary, or temporary or permanent, living in a foreign country, especially where a language completely unrelated to one's mother tongue is spoken, presents migrant people with a variety difficulties, especially when they first enter intercultural "contact zones."

According to Pratt (1991), a “contact zone” is a place where migrants' own cultures, languages, and beliefs "meet, clash, and grapple" with new ones "in contexts of asymmetrical relations of power" (p. 34). The experiences of Korean (im)migrants are not exceptional. Most studies of the hardships Korean (im)migrants face in the United States as the host country, including those focused on Korean (im)migrant mothers, have been conducted in psychology, nursing, and gender studies but rarely in language education. Also, possibly because the phrase seems self-explanatory to most observers, Pratt's (1991) notion of “contact zone" has been under-used to investigate the lives of Korean (im)migrant mothers in the United States, where they must deal with different languages and cultures. Furthermore, little attention has been paid to the "intersectionality" (Crenshaw, 1989) of the multiple identifications of Korean (im)migrant mothers as Korean (im)migrants, women, mothers, wives, and previous owners of often high levels of social and economic capital (Bourdieu, 1991), and how their intersectionality might affect their lives in contact zones. Thus, in this study, a theoretical framework comprising the concepts of both "contact zone" (Pratt, 1991) and "intersectionality" (Crenshaw, 1989) is employed to investigate the experiences of Korean (im)migrant mothers living in contextualized contact zones in the United States, particularly as these entail the interplay of their multiple identifications. 


\section{Literature Review}

\section{Contact Zone(s)}

When coining the term "contact zone" in "Arts of the Contact Zone," Pratt (1991) used late 16th and early 17 th century Peru as an example of a contact zone in a global and macro context. There, the native Quechua people suffered many difficulties imposed by the Spanish empire. Pratt considered a letter written to the Spanish king by an indigenous man known as Guaman Poma to be an artifact of a contact zone in that it was a manifestation of two languages and two cultures impacting each other and producing a new integrated but imbalanced form, in which Spanish was dominant over Quechua. Pratt used the Peruvian situation as a metaphor for her own teaching experience in local and micro-contexts, describing the classroom as a contact zone rather than "a homogeneous community or a horizontal alliance," in which "all the students in the class had the experience of hearing their culture discussed and objectified in ways that horrified them" (p. 44). She added that the students were diverse and heterogeneous enough to be ignorant of each other's roots and possibly hostile, resulting in the marginalization of some students.

Tracing the roots of the United States back to the "first massive immigration of Europeans in the seventeenth century (p. 52)," Bizzell (2002) proposed that the United States was a contact zone comparable to the example of Peru in Pratt's study and, to understand how different groups intermingled over time, proposed that English studies should be reorganized by "historically defined contact zones, moments when different groups within the society contended for power to interpret what was going on" (p.53).

While the concept of contact zones was originally applied to broad macro-level social configurations, in social science and educational research the concept is largely applied to 
diverse micro-level school settings including classrooms (Canagarajah, 1997; Harris, 1995; Malsbary, 2014; West (2012), basic writing tutorials (Baker, 2006), school cafeteria (Kelly, 2012), a global university (Kenway \& Bullen, 2003), community college ESL (Curry, 2001), and freshman composition courses (Lu, 1994). On the other hand, both Miller (1994) and Beauvais (1996) criticized Pratt for not demonstrating how the concept of contact zone could be applied in English language teaching and learning but tried to fill the gap. While Key (2002) looked outside the school, her setting was still a classroom offered in a community center and led by a teacher.

Among the few applications of the notion in micro-level contexts beyond school or classroom settings were Anderson's (2012) use of the concept in a study of interactions in medicine, especially between patients and healthcare providers, and Torres's (2007) examination of Latino/a writers' code-switching strategies in the literary contact zone. Canagarajah (2015) claimed that all social spaces where acceptance and renegotiation are possible should be considered contact zones. Patel (2012), conducting a participatory action study of a professional internship for newcomer youths outside of school, even presented one micro-level layered contact zone, rather intentionally designed rather than organically generated.

\section{Korean Immigrant Mothers' Struggles and Intersectionality}

Under any circumstances, (im)migration is stressful as uprooted people must go through a demanding adjustment process (Kim, 1997). For many Korean (im)migrants, their lives in the United States may prove disappointing compared to their anticipations before (im)migrating. Acquiring competence in a new language is not their only learning task. They are likely to experience difficulties adjusting to new cultural and social norms. For various reasons, this process seems to be especially stressful for Korean (im)migrants (Hurh \& Kim, 1990; Kuo, 1984; Noh \& Avison, 1992). Lee and Woo (2013) found that Korean (im)migrants' general 
well-being was affected by socio-economic stressors, lack of English proficiency, and financial hardship.

Until very recently, research on immigration has been notably gender-blind (Yakushko \& Morgan-Consoli, 2014). Yet without discounting the hardships and challenges that (im)migrants of either gender endure, it is reasonable to assume that there are differences between them, which warrants focusing separately on the challenges encountered by (im)migrant women listening to their voices. In a similar vein, Seo et al. (2020) conducted an extensive literature review to investigate how the Korean traditional gender ideology of "wise mother good wife" was transacted in the adjustment of Korean immigrant women. They suggested looking at the issue from the perspective of intersectionality to understand the gendered lived experiences specifically unique to Korean immigrant women.

Intersectionality, as defined by Crenshaw (1990), refers to the interactive effects of multiple social constructs such as race, class, gender, and religion, and more, which create barriers and pitfalls in the lived experiences of individuals and groups who hold multiple marginalized identities (Bowleg, 2008; Hurtado, 2003; Syed, 2010) beyond those associated with any one of such identities (Seo et al., 2020). Korean (im)migrant women's lives are complicated by cultural, gender, racial, and perhaps other multiple identities that differentiate them from the American mainstream.

The unique lived experiences of Korean (im)migrant women have been studied mostly in women's studies, psychology, and nursing and have reportedly focused on their well-being under the effects of isolation, stress, and depression due to overwhelming childcare (Moon, 2003); language barriers (Seo et al., 2020); and socio-economic downward mobility (Kim \& Yu, 1996). This study therefore extends the literature by contextualizing Korean (im)migrant women's 
gendered immigration lives in their layered contact zones, with a focus on those who owned high levels of linguistic, cultural, and economic capital prior to (im)migration but which has low or no currency in the U.S.

\section{Method}

\section{Feminist Cyber-ethnography}

Employing feminist cyber-ethnography, especially Rybas and Gajjala's (2007) emphasis on the intersubjective researcher positionality of "epistemologies of doing," this study attempts to answer the following research questions.

\section{Research Questions}

1. How does the intersectionality of the multi-identifications of Korean (im)migrant mothers who came to the United States as trailing spouses reveal micro-level contact zones in., the macro-level contact zone of the U.S?

2. In what ways have the multi-identities of the women brought them into contact with power-bounded linguistic, cultural and social differences?

\section{Setting and Context}

For this study, part of a five year long longitudinal project from 2014-2018, using purposive and convenient sampling, I chose four Korean (im)migrant mothers whom I met in an online English language learning community called SEED in order to examine the contextualized contact zones perceived by Korean (im)migrant mother with relatively high levels of linguistic, cultural, and economic capital. The community was founded in August, 2011, by a Korean immigrant woman completing a pharmacy doctorate at the time, nesting in one of the biggest online ethnic communities for Korean (im)migrant women in the United States. The community restricted membership to applicants able to participate in weekly meetings held solely in English. 
Most of the members were highly educated trailing spouses and mothers from affluent families. Thus, it was the right place from which to recruit the participants who meet the criteria in terms of capital. Other criteria to be satisfied were: 1) those who were married with children, 2) those who had lived in the United States for several years, and 3) those who joined the community before August 2012, and posted in the community forum (called café) during the period of July 2012 to August 2014, given that only posts during the time were accessible by the time of data collection. In terms of legal status, Sandra, Regina, and Angela were permanent residents whereas Kirin was still holding an F2 dependent visa. Thus, I use the term "(im)migrant" to include both lawfully permanent immigrant and temporary migrant mothers. As a founding member of the community myself, I have known the participants since 2011 . Table 1 shows the demographic information of the participants: two current members (Sandra and Regina) and two former members (Angela and Kirin). All the names are pseudonyms chosen by each participant.

Table 1

Demographic Information of the Participants

\begin{tabular}{|l|l|l|l|l|l|l|}
\hline Name & $\begin{array}{l}\text { Age at } \\
\text { time of } \\
\text { data } \\
\text { collection }\end{array}$ & $\begin{array}{l}\text { (Im)migration } \\
\text { Year/ Region }\end{array}$ & Family & Profession & $\begin{array}{l}\text { Past } \\
\text { profession }\end{array}$ & Education \\
\hline Sandra & Early 40s & $\begin{array}{l}2007 / \text { Boston, } \\
\text { MA }\end{array}$ & $\begin{array}{l}\text { Husband } \\
\text { (Engineer) } \\
\text { 2 children }\end{array}$ & $\begin{array}{l}\text { Stay-at- } \\
\text { home mom }\end{array}$ & Pharmacist & $\begin{array}{l}\text { B.A. in } \\
\text { Pharmacy }\end{array}$ \\
\hline Regina & Mid 40s & $2003 /$ Texas & $\begin{array}{l}\text { Husband } \\
\text { Engineer) } \\
\text { 2 children }\end{array}$ & Pharmacist & $\begin{array}{l}\text { Computer } \\
\text { Programmer }\end{array}$ & $\begin{array}{l}\text { Doctor in } \\
\text { Pharmacy }\end{array}$ \\
\hline Angela & Mid 40s & $\begin{array}{l}2005 / \\
\text { Maryland }\end{array}$ & $\begin{array}{l}\text { Husband } \\
\text { (Post- } \\
\text { Doc) } \\
\text { 1 Child }\end{array}$ & $\begin{array}{l}\text { Kindergarten } \\
\text { teacher }\end{array}$ & $\begin{array}{l}\text { Kindergarten } \\
\text { teacher }\end{array}$ & $\begin{array}{l}\text { M.A.s in } \\
\text { Education }\end{array}$ \\
\hline Kirin & Late 30s & 2011/ Texas & $\begin{array}{l}\text { Husband } \\
\text { (Ph.D. } \\
\text { student) } \\
\text { 2 Children }\end{array}$ & $\begin{array}{l}\text { Stay-at- } \\
\text { home mom }\end{array}$ & $\begin{array}{l}\text { Worked for } \\
\text { a foreign } \\
\text { company }\end{array}$ & $\begin{array}{l}\text { B.A. in } \\
\text { Economics }\end{array}$ \\
\hline
\end{tabular}




\section{Data Collection}

Buch and Staller (2006) describe three primary forms of data collected in feminist ethnographic studies: "ethnographic talking to informants, observations, and social artifacts" (p. 209). This study also collected these three forms of data, although, given the nature of cyberethnography, most of the data were archival data (web posts) and interview data. Additionally, follow-up focus group text messages and observation of weekly meetings were also utilized.

The majority of archival data were online posts written by each participant as in either original posts or replies in the community café (blog-like) forum. The four participants made a total of 1,941 postings between July 2012 and August 2014. Personal emails and text messages (Kakao Talk: a Korean mobile instant messaging application) between each participant and me were also included. In addition, semi-structured individual interviews were conducted via Zoom in spring 2018 except for Kirin, who was visiting Korea, so that the only option we found was to use the Kakao Talk audio calling function. Except for Kirin the other three voluntarily turned their cameras on even before I asked them, so we could see each other and feel comfortable as if we were having a casual chat. That aligned with what Buch and Staller's (2016) emphasis on the benefits of informal conversations that can provide richer understanding than formal interviews in feminist-ethnographic studies. All interviews were conducted in Korean and audio-recorded, labeled, and stored in my computer securely both before and after my partial transcriptions. As a participant observer, I conducted direct observations of four weekly meetings of Regina's and Angela's groups respectively between February and April, in 2017. Follow-up focus group texts messages were collected in our Kakao chat room where Sandra, Regina, and Angela, being extremely supportive, allowed me to ask further clarifying questions. 


\section{Data Analysis}

Thematic analysis (Cresswell, 2014) was used for my feminist cyber-ethnography because it provided a way not only to construct explicit themes but also to make explicit the themes that are implicit to the stories that my participants wrote and told. The thematic analysis was a continuous process that began when I started collecting the archival data and continued throughout all phases of the study. Given that I already had a large corpus of archival data, coding them started before I conducted participant observation and individual interviews. "Winnow[ing]" the lengthy café postings, a "process of focusing in on some of the data and disregarding other parts of it" (Cresswell, 2014, p. 195) was necessary in the beginning. Following Creswell's “iterative” (p. 244) steps for analyzing qualitative data for an ethnographic study, I tried to create as many codes as possible at early phases as all the occurring topics were units of analysis, first coding the data of each participant and next comparing codes across participants to identify and support common themes. After identifying key words or phrases, I "grouped, regrouped and relinked in order to consolidate meaning and explanation" (Grbich, 2007, p. 21). Thematic analysis mainly relied on an inductive, bottom-up approach, yet my analytic memos I wrote while coding helped the coding decisions related to the theoretical and conceptual frameworks of the study. I took measure to ensure reliability, validity, and generalizability as Cresswell (2014, pp. 201-203) suggested: cross-checking with the participants, triangulating data from different sources, member-checking, conducting peerdebriefing, and having external translators review the data.

\section{Findings}

Ostensibly well-resourced Korean immigrant mothers shared their encounters in their diverse contact zones in the United States as the macro contact zone. Their intersecting identities as 
Korean (im)migrant women, wives, and mothers located them in their particular contact zones, as shown in Figure 1. This paper demonstrates three kinds of contextualized contact zones they experienced: those take for granted, those associated with being mothers, and those in the same ethnic community and even home.

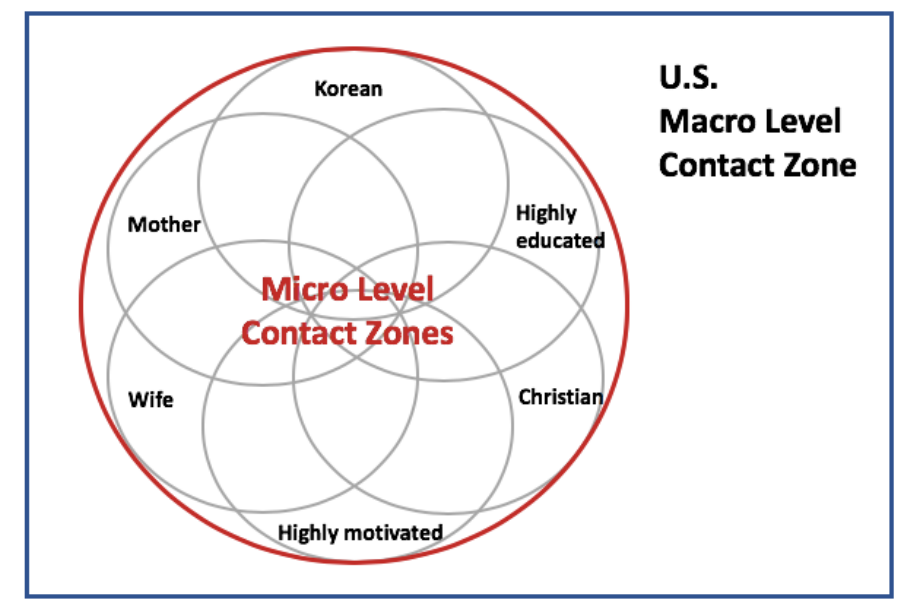

Figure 1 Micro-level contact zones reflecting the intersectionality of the Korean (im)migrant mothers' multi-identifications in the United States, their macro-level contact zone

\section{The Taken for Granted Contact Zones}

As shown in the literature on Korean (im)migrant women's lives and hardships, the participants in this study confronted various contact zones regardless of their advanced command of English language and cultural competence gained by living in the United States as foreigners in that encountering unfamiliar language and cultural phenomena was integral to their official status as (im)migrants.

When asked if she had encountered any embarrassing or difficult moments, Sandra calmly replied, "I always had difficulties, of course," referring to language-related experiences as a hospital volunteer, in which she mostly helped patients and visitors who asked for directions. She had a hard time making her explanations of the different elevators and floors understood. 
One time, a middle-aged Caucasian man asked for directions to a certain building. Wanting to make sure she had understood his question correctly, as some buildings had very similar names, she replied, "Excuse me?" The man said, "Forget it!" while giving her a hostile look. Whenever such incidents occurred, Sandra felt she was treated rudely because she was Asian and a foreigner. She added that although the incidents made her uncomfortable, she tried not to take them personally and did not attribute them to her gender but to being a foreigner without perfectly fluent English. Sandra said that she began to question whether she could carry out any given responsibilities and would have felt anxious if they were paid employment when the expectation would be much higher.

During the interview, it was noticeable that Sandra always commented on a person's educational background when to him or her. Residing in Boston, Sandra's experiences in her contact zones seemed related to her attitudes toward her social position in relation to whether others had any connection to Harvard University. Sandra's perceptions in this contact zone experience might have been different if she had lived in a different region in the United States. Regardless of her upbeat personality, Sandra clearly faced some challenges in the contact zone where she lived, a city that was host to a preeminent world-class university.

The counterpart's social position, and both the explicit and implicit power attendant to that position, also placed Regina into distressed contact zones. Regina also shared embarrassing and challenging moments in the United States due to her language barrier. Describing her experience learning English, she recalled how she could neither understand nor speak it at all when she first came to the United States. An episode in which a teacher at her first English placement test in a U.S. college, who she perceived had a social and cultural power than she did, 
misunderstood and pointed at her shoes when Regina said "huge" seemed to be engraved in her recollection as a funny yet bitter memory.

Interestingly, Regina's contact zone experiences seemed particularly related to confrontations with Caucasian women, as shown by her phrase "white woman trauma," which originated in a frustrating experience that happened when her family was on a, scuba diving vacation in Hawaii. A white woman about Regina's age angrily accused her of stealing her towel, which so stunned Regina that she froze and could not say anything in her defense, a common reaction when one feels negatively stereotyped because of some aspect of his/her identity such as race or gender (Spender et al., 1999). What made the situation worse was no one around them bothered to help Regina even though it was self-evident that she was not a thief. Believing that her English will never be more eloquent than that of Caucasian women, after this incident, Regina has remained "feeling belittled" whenever she is confronted by Caucasian women, especially those she perceived as being in a socially higher position.

Both Sandra and Regina imputed their negative contact zone experiences to their lack of English language competency and lowered social positionality as "foreigners" rather than blaming the perpetrators of the incidents, who prejudged and marginalized them. Also, neither explicitly attributed the incident to being women. When prompted, they admitted that "Korean (im)migrant men might have been treated differently in some occasions", although they still considered their foreign appearance and lack of English language fluency as primary causes of their mistreatment.

\section{Contact Zone Experiences as Mothers}

Given their multiple identifications as Korean (im)migrant women in the United States, and their language barriers and cultural differences, the participants were inevitably finding 
themselves in challenging situations in contact zones. Although the degree of hardship might be greater than they had anticipated before (im)migration, they accepted its inevitability and tried to "deal with it" or "let it go". However, their identities as mothers of young children made them more vulnerable to their experiences in contact zones.

In this section, I show discuss how the women's identification as mothers, in particular, affected the impact of their contact zones. Kirin, who had experienced living in the United States as an international student at a prestigious college, was now the mother of a son and had to enter the school contact zone, where she experienced difficulties despite the advanced English skills and cultural competency she developed in her previous U.S. residency. From community members who had been living and sending their children to school in the United States for longer periods, Kirin had been learning how not to take events personally.

However, Kirin admitted that living in the country as a migrant mother presented various negative contact zone episodes. Kirin described an issue she had encountered in the school contact zone, where Kirin's kindergartener son, Michael, had a substitute teacher who would never make eye contact with her, making Kirin uncomfortable despite her persistent efforts to make eye contact and start small talk with her. While she was worried if it happened "because her English", Kirin's concern was, however, not for herself but for her son. She sighed, saying, "What if she did the same thing to my boy!"

Like most Korean (im)migrant mothers, Kirin could not avoid worrying about how her child was treated, especially at school. Based on her experience of feeling excluded by the substitute teacher who never made eye contact with her, she was afraid that her son would experience the same exclusion. Whether he did is unknown, but the point is that Kirin was worried that the teacher's cold attitude toward her and possibly other foreign parents would be 
transferred to Michael as well. She considered this concern "inevitable", as any parent would be sensitive to the possibility that her child would suffer disadvantages.

That the mother identity intensifies experiences in contact zones was also displayed in a post Sandra wrote in the SEED on May 9, 2014, in which she was asking for advice regarding parent volunteering.

Hello, [SEED] sisters, how did you do school volunteering? My son is only in pre-K, but the school keeps sending emails about fundraising, donations, and volunteering. I thought I should do something at least. So I signed up for an event last Thanksgiving. I got a notification that said the event is taking place tomorrow. My job will be reading a book to the class as a mystery reader. The point is I show up without my son knowing. I admit it is not a big thing, yet somehow I am feeling pressure and nervous, asking myself why I signed up for it! Thus, I went to Barnes \& Noble, and fortunately, a lot was on sale so I ended up spending $\$ 70$ on books, even with two coupons. LOL. Healthy spending, huh?

Given the light-hearted personality she generally projected into her posts and her English fluency, it was somewhat surprising to learn that she felt pressure about volunteering at her older son's school, especially as she had described previous experiences volunteering, and her task was simply to read a book to the class, as she described, "not a big thing". Her English fluency, as well as her sense of humor, seemed to be well beyond what was required for the task. The content of this message was not too serious for the SEED members to concern about her ability to carry out the task. Still, it showed that even a person like Sandra, who was positive and willing to engage, could also feel discomfort in an entirely English-speaking context, especially when her children were involved. As an immigrant mother whose children attended a school in which most students were Caucasians, she did not hesitate to be assertive in the contact zone, which might have been less intimidating to her than to other Korean (im)migrant mothers, and Her outgoing personality notwithstanding, she might have reacted differently in this case if the event had not been related to her sons, as it was their faces she was afraid of losing, not her own. This incident illustrates one reason why Korean (im)migrant mothers are often reluctant to volunteer 
at their children's schools although it is one of most important mainstream contact zones for them (Lee \& Moon, 2011). Due to their perceived language barriers, they are worried about the possible consequences their foreign English might cause for their children.

\section{Contact Zones within the Same Ethnic Community and at Their Own Home}

Generally, contact zones are assumed to exist outside of one's comfort zone. Thus, it might be presumed that for these participants contact zones were always outside their communities of Korean (im)migrant mothers and of course their own homes. However, these contexts were also contact zones for them, at least to some extent, who had low opportunities for social relations outside as Canadian immigrant mothers in Norton's (2013) study. In interactions between Korean (im)migrant mothers it may be taken it for granted that "the situation is governed by a single set of rules or norms shared by all participants" (Pratt, 1991, p. 38), given their same ethnicity and gender. However, some differentials in power, culture, and economics (Anderson, 2012) within the same ethnic group created layers of contact zones for the participants.

In answering why she joined SEED, Angela cited loneliness stemming from the isolation of childcare and the financial gap that she had perceived as separating her Korean (im)migrant neighbors from her family. Her husband occupied a relatively "low-paying long-term postdoctoral position", a point she emphatically emphasized. The research university where Angela's husband worked was one of the most prestigious in the United States, suggesting that in her area, the Korean (im)migrant families of established scholars and researchers dominated a social scene in which her family "could not afford to participate". She could not join conversations about luxury spending with acquaintances who seemed always to be "boasting" about the trips they had taken or were planning, or fancy restaurants in which Angela's family "could not even dream of" 
dining. A presumptive comfort zone within the same ethnic community (acquaintances) rather turned out to be a contact zone for Angela in which she continuously confronted the financial differences between her family and her Korean (im)migrant mother acquaintances. That "they [acquittances] were different in social economic status" made Angela, who had sought emotional support and comfort from the ethnic community, instead felt lonelier, as if she was an "outsider within" (Collins, 1986; Kwon, 2015), discouraging her so that she preferred staying home and away from these acquaintances.

Not only the awareness of financial differences within the Korean (im)migrant mothers' community but also different levels of English language competency and varying levels of aspiration to improve the language also created contact zones. For example, Kirin "felt alienated" within her immediate community. As the wife of a young doctoral student, Kirin had occasion to gather with other Korean graduate students' wives, who were similar to her in age, had young children, came from at least middle-class families, and were college-educated, so they had "everything in common except that none of them spoke fluent English or was willing to invest in studying the language". Having earned a B.A. at a prestigious U.S. university and worked in a foreign company in Korea before her migration to the United States, Kirin wanted to hone her already advanced English language skills so she could compete for a mainstream job market when an opportunity arose. Kirin kept joining in conversations about "how the life of a Ph.D. student's wife was depressing", in large part because they were "not allowed to work" and thus "wholly responsible for endless household chores". Whenever she suggested they study English with her, however, Kirin's acquaintances did not take her seriously, even questioning why Kirin would want to "make her life more difficult". Regarding Kirin as ambitious, they did not want to bother themselves to set time to study English. Thus, Kirin's perceived 
ambitiousness set her apart in the company of Korean (im)migrant mothers who did not want to bother learning English, and this ostensible comfort zone in fact came to be a contact zone for her. Feeling alienated from this group of Korean (im)migrant mothers, Kirin sought another community in which she could share her English language competency and aspirations to improve it.

Whereas Angela and Kirin's “outsider within” experience occurred in contact zones within the same ethnic community, Regina experienced a contact zone at her own home where her view of life conflicted with that of her husband, whose opinions usually prevailed. She attributed this to her "financial dependence on her husband's income" and "traditional Korean power relations between man and wife", as illustrated in the following episode. Right after accompanying her husband to the United States, where he wanted to have work experience, Regina lacked the confidence "even to open her mouth to speak" despite her high English literacy skills. So she expressed the wish to attend ESL classes to gain some speaking confidence. Instead, she ended up taking college courses in English for credit because of her husband's "strong objection to ESL classes as a waste of money and time". Admittedly, she could "see the benefits of taking college-level courses" since she planned "to pursue a career as a pharmacist”. Nevertheless, jumping right into world of native English speakers instead of gradually moving away from her linguistic comfort zones, especially "not under my [her] own volition", displeased her. Therefore, Regina's home, instead of being the ultimate place of refuge, was occasionally transformed into a contact zone where opinions and gender roles clashed. That she "needed her husband's permission to do anything", according to Regina, stemmed from her "financial dependence on my [her] husband". This condition dovetailed 
perfectly with the Korean traditional belief that the man leads a house and the wife supports her husband.

In sum, all four participants shared the identity of being Korean (im)migrant mothers living in the United States, a macro-level contact zone. While their living contexts were not exactly the same, what they had in common was that the experience of living at the intersection of their multiple identities as Korean, (im)migrant, women, wives, and mothers, which were entangled with their encounters in various micro-level contact zones.

\section{Discussion}

The findings revealed that the four Korean (im)migrant mothers encountered particular and layered micro-level contact zones (Pratt, 1991), where they engaged in interactions that included "conflicts or systematic social differences" with interlocutors who were "from different classes or cultures, or one party is exercising authority" (p. 38). Both Sandra and Regina confronted such incidents, at the volunteering venues and vacation place, respectively, highlighting the intersection of their socially marginalized identities as Korean (im)migrant (ethnic minority), non-native English speaker (low level of cultural capital compared with native English speakers), and women (gender discrimination). Those social practices could impose “(im)migrant language learners [to be] considered illegitimate speakers of English" (Norton, 2013, p. 168).

Moreover, their shared identity as mothers, as shown in Kirin's and Sandra's episodes, added unique and bitter layers to the contact zones in which they found themselves. The inscribed gender ideology that a woman's life is evaluated according to the success of her motherhood (Choi, 2009) along with the traditional Korean idealization of the "wise mother, good wife" was intensified by the women's (im)migrant status (Seo et al. 2020). Accordingly, 
the mothers put everything on the line to protect their children from having to confront severe contact zones as much as possible. This position aggravated the extent of their contact zones.

Besides, the participants' intersecting identities provided expanded examples of clashes occurring in the contact zone(s). The clashes reported in this study extend beyond the seemingly apparent clashes any (im)migrant adults might confront, drawn from differences in race, gender, religion, and class. Even within the same ethnic women's community, "the interplay of multiple social categories," such as Kirin's aspiration to move upward in the mainstream by improving her English skills, or Angela's low economic capital compared with her affluent neighbors, "created different or unique experience[s] of marginalization" (Cole, 2009; Shields, 2008; cited in Seo et al., 2020, p.2).

Finally, traditional Korean gender roles, in which the husband leads the family as breadwinner while the wife is a "good wife," an "interesting conversational partner for their [her] husband" (Choi, 2009, p. 7), clashed with Regina's desire to be independent. Her aspiration, influenced by emphasis on greater gender equality in the United States (Goss, 2013), created another unique contact zone within her home. The patriarchal order in Regina's family, reinforced by her financial dependence on her husband's income, prevented Regina from making any critical decision by herself.

Not all Korean (im)migrant mothers would encounter the exactly the same contact zones described in this study, nor would those described happen only to Korean and not to other (im)migrant mothers. However, it is evident that the participants' intersecting identities either directly or indirectly created and even exacerbated their experiences in the micro-level contact zones within the macro-level contact zone. Power relations exist in all interactions, and their dynamics reflect the multiple identifications at play in layered contact zones. 


\section{Conclusions and Implications}

This feminist cyber-ethnography is an exploration of the intersecting identities of four Korean (im)migrant mothers' multiple identities as Koreans, wives, and mothers in relation to their encounter in their various contact zones. This study has two implications. First, by contextualizing layered contact zones these Korean (im)migrant mothers experienced through the lens of internationality, it responds to Miller's (1994) critique that Pratt did not exemplify how her participants negotiated different perspectives and identities when they were put on the line. Second, this study expands the literature that shatters gender blindness in research on immigrants by presenting Korean (im)migrant mothers' unique voices and lived experiences by focusing on experiences in contact zones through the lens of intersectionality. This extension is meaningful in that previous scholarship has paid little attention to Korean (im)migrant mothers, migrants from a developed country with cosmopolitan dispositions. By initiating the examination of Korean (im)migrant mothers' experiences in layered contact zones from the perspective of intersectionality, this study opens avenues for future research on their unique strategies to survive in contact zones.

\section{ABOUT THE AUTHORS}

Dr. Su Jin Park is an independent researcher who has been adjunct faculty in Indiana University Bloomington and Northwest since she received her Ph.D. from Literacy, Culture, and Language Education at IUB. This piece is a part of her Ph.D. dissertation awarded TIRF (The International Research Foundation) dissertation grant 2017.

Dr. Beth Lewis Samuelson is Associate Professor of Literacy, Culture and Language Education and Adjunct Professor of African Studies at the Indiana University Bloomington. Her research has focused on language policy in Rwanda and community engagement and 
international service learning. She has earned degrees from the University of WisconsinMadison, the University of Southern California, and the University of California, Berkeley.

Inquiries can be made to Su Jin Park: park268@iu.edu

\section{References}

Anderson, C. M. (2012). Editor's preface: Contact zones and safe houses. Literature and Medicine, 30(1), pp. vii-xx. https:doi.org/10.1353/1m.2012.0013

Baker, B. (2006). Safe houses and contact zones: reconsidering the basic writing tutorial. Young Scholars in Writing, 4, 64-72.

Beauvais, P. J. (2002). First contact: Composition students' close encounters with college culture. In J. M. Wolff (Ed.), Professing in the contact zone: Bringing theory and practice together. (pp. 21-47). National Council of Teachers of English.

Bizzell, P. (2002). Multiculturalism, contact zones, and the organization. In J. M. Wolff (Ed.), Professing in the contact zone: Bringing theory and practice together. (pp. 48-57). National Council of Teachers of English.

Bourdieu, P. (1986). The forms of capital. In J. Richardson (Ed.), Handbook of theory and research for the sociology of education (pp. 241-258). Greenwood Press.

Bourdieu, P. (1991). Language and symbolic power. Harvard University Press.

Bowleg, L. (2008). When Black+ lesbian+ woman $\neq$ Black lesbian woman: The methodological challenges of qualitative and quantitative intersectionality research. Sex Roles, 59(5-6), 312-325. https://doi.org/10.1007/s11199-008-9400-z 
Buch, E. D., \& Staller, K. M. (2006). The feminist practice of ethnography. In S. N. Hesse-Biber, \& P. L. Leavy (Ed.), Feminist research practice (pp. 187 - 222). Sage. https://dx.doi.org/10.4135/9781412984270.n7

Canagarajah, A. S. (1997). Safe houses in the contact zone: Coping strategies of AfricanAmerican students in the academy. College Composition and Communication, 48(2), 173-196. https://doi.org/10.2307/358665

Canagarajah, A. S. (2015). Negotiating mobile codes and literacies at the contact zone: Another perspective on South African township schools. In Language, literacy and diversity (pp. 50-70). Routledge.

Choi, H. (2009). "Wise mother, good wife": A transcultural discursive construct in modern Korea. Journal of Korean Studies, 14(1), 1-33. https://doi.org/10.1353/jks.2009.0004

Cole, E. R. (2009). Intersectionality and research in psychology. American Psychologist, 64(3), 170. https://doi.org/10.1037/a0014564

Collins, P. H. (1986). Learning from the outsider within: The sociological significance of Black feminist thought. Social Problems, 33(6), s14-s32. https://doi.org/10.2307/800672

Crenshaw, K. (1989). Demarginalizing the intersection of race and sex: Black feminist critique of antidiscrimination doctrine, feminist theory and antiracist politics. University of Chicago Legal Forum, 1989, 139-168.

Cresswell, J. W. (2014). Research design: Qualitative, quantitative, and mixed methods approaches. Sage publications.

Curry, M. J. (2001, April). Adult ESL students in the contact zone: Exploring the effects of multiple educational attainment levels on the community college writing classroom. 
[Paper presentation]. American Educational Research Association (AERA) Conference, 2001, Seattle. U.S.

Goffman, E. (1955). On face-work: An analysis of ritual elements in social interaction. Psychiatry, 18(3), 213-231. https://doi.org/10.1080/00332747.1955.11023008

Goss, K. A. (2020). The paradox of gender equality: How American women's groups gained and lost their public voice: University of Michigan Press.

Grbich, C. (2007). Qualitative data analysis: An introduction. Sage.

Harris, J. (1995). Negotiating the contact zone. Journal of Basic Writing, 27-42. https://www.jstor.org/stable/43443647

Hurh, W. M., \& Kim, K. C. (1990). Correlates of Korean immigrants' mental health. Journal of Nervous and Mental Disease, 178(11), 703-711. https://doi.org/10.1097/00005053199011000-00006

Kelly, C. (2012). The cafeteria as contact zone: Developing a multicultural perspective through multilingual and multimodal literacies. Journal of Adolescent \& Adult Literacy, 56(4), 301-310. https://doi.org/10.1002/JAAL.00143

Kenway, J., \& Bullen, E. (2003). Self-representations of international women postgraduate students in the global university 'contact zone'. Gender and Education, 15(1), 5-20. https://doi.org/10.1080/0954025032000042112

Key, D. (2002). Safe houses and sacrifices: Filling the rooms with precious riches. In J. M. Wolff (Ed.), Professing in the contact zone: Bringing theory and practice together (pp. 102118). National Council of Teachers of English.

Kim, C. J. (1999). The racial triangulation of Asian Americans. Politics \& Society, 27(1), 105138. https://doi.org/10.1177/0032329299027001005 
Kim, E. H. \& Yu, E-Y. (1996). East to America: Korean American life stories. The New Press.

Kuo, W. H. (1984). Prevalence of depression among Asian-Americans. Journal of Nervous and Mental Disease, 172(8), 449-457. https://doi.org/10.1097/00005053-198408000-00002

Kwon, H. (2015). Intersectionality in Interaction: Immigrant Youth Doing American from an Outsider-Within Position. Social Problems, 62(4), 623-641. https://doi.org/10.1093/socpro/spv019

Lee, K. H., \& Woo, H. (2013). Stressors, social support, religious practice, and general wellbeing among Korean adult immigrants. Journal of Evidence-Based Social Work, 10(5), 421-434. https://doi.org/10.1080/15433714.2012.759483

Lee, Y.-j., \& Moon, S.-G. (2011). Mainstream and ethnic volunteering by Korean immigrants in the United States. Voluntas: International Journal of Voluntary and Nonprofit Organizations, 22(4), 811-830. https://doi.org/10.1007/s11266-010-9176-y

Lew, J. (2006). Asian Americans in class: Charting the achievement gap among Korean American youth. Columbia University Press.

Lim, I.-S. (1997). Korean immigrant women's challenge to gender inequality at home: The interplay of economic resources, gender, and family. Gender \& Society, 11(1), 31-51. https://doi.org/10.1177/089124397011001003

Lu, M.-Z. (1994). Professing multiculturalism: The politics of style in the contact zone. College Composition and Communication, 45(4), 442-458. https://doi.org/10.2307/358759

Malsbary, C. B. (2014). “It's not just learning English, it's learning other cultures”: Belonging, power, and possibility in an immigrant contact zone. International Journal of Qualitative Studies in Education, 27(10), 1312-1336. https://doi.org/10.1080/09518398.2013.837210 
Miller, R. E. (1994). Fault lines in the contact zone. College English, 56(4), 389-408. https://doi.org/10.2307/378334

Moon, S. (2003). Immigration and mothering: Case studies from two generations of Korean immigrant women. Gender \& Society, 17(6), 840-860. https://doi.org/10.1177/0891243203257200

Noh, S., \& Avison, W. R. (1992). Assessing psychopathology in Korean immigrants: Some preliminary results on the SCL-90. The Canadian Journal of Psychiatry, 37(9), 640-645. https://doi.org/10.1177/070674379203700908

Norton, B. (2013). Identity and language learning: Extending the conversation. Multilingual matters.

Ogbu, J. U., \& Simons, H. D. (1998). Voluntary and involuntary minorities: A culturalecological theory of school performance with some implications for education. Anthropology \& Education Quarterly, 29(2), 155-188. https://doi.org/10.1525/aeq.1998.29.2.155

Park, L. S. (2005). Consuming citizenship: Children of Asian immigrant entrepreneurs. Stanford University.

Patel, L. (2012). Contact zones, problem posing and critical consciousness. Pedagogies: An International Journal, 7(4), 333-346. https://doi.org/10.1080/1554480X.2012.715738

Pratt, M. L. (1991). Arts of the contact zone. Profession, 91, 33-40. https://www.jstor.org/stable/25595469

Rybas, N., \& Gajjala, R. (2007). Developing cyberethnographic research methods for understanding digitally mediated identities. Forum Qualitative Sozialforschung / Forum: Qualitative Social Research, 8(3). http://dx.doi.org/10.17169/fqs-8.3.282 
Seo, Y. J., Cheah, C. S., \& Cho, H. S. (2020). The gender ideology of 'Wise Mother and Good Wife' and Korean immigrant women's adjustment in the United States. Nursing Inquiry, e12357. https://doi.org/10.1111/nin. 12357

Shields, S. A. (2008). Gender: An intersectionality perspective. Sex Roles, 59(5-6), 301-311. https://doi.org/10.1007/s11199-008-9501-8

Spencer, S. J., Steele, C. M., \& Quinn, D. M. (1999). Stereotype threat and women's math performance. Journal of Experimental Social Psychology, 35(1), 4-28. https://doi.org/10.1006/jesp.1998.1373

Syed, M. (2010). Disciplinarity and methodology in intersectionality theory and research. American Psychologist, 65(1), 61-62. https://doi-org.proxyiub.uits.iu.edu/10.1037/a0017495

Torres, L. (2007). In the contact zone: Code-switching strategies by Latino/a writers. Melus, 32(1), 75-96. https://www.jstor.org/stable/30029707

Yakushko, O., \& Morgan-Consoli, M. L. (2014). Gendered stories of adaptation and resistance: A feminist multiple case study of immigrant women. International Journal for the Advancement of Counselling, 36(1), 70-83. https://doi.org/10.1007/s10447-013-9191-y

Intersectionality of Korean (Im)migrant Mothers 